\title{
Anti-Very Late Antigen-1 Monoclonal Antibody Modulates the Development of Secondary Lesion and T-Cell Response in Experimental Arthritis
}

\author{
Angela lanaro, Carla Cicala, Antonio Calignano, Victor Koteliansky, Philip Gotwals, \\ Mariarosaria Bucci, Roberto Gerli, Luca Santucci, Stefano Fiorucci, and \\ Giuseppe Cirino
}

\begin{abstract}
Dipartimento di Farmacologia Sperimentale via Domenico Montesano 49 (Al, CC, AC, MB, GC), Napoli, and Sezione di Medicina Interna e Scienze Oncologiche (RG) and Sezione di Gastroenterologia ed Epatologia (LS, SF), Dipartimento di Medicina Clinica e Sperimentale, Universita' degli Studi di Perugia, Perugia, Italy; and Biogen 14, Cambridge Center (VK, PG), Cambridge, Massachusetts

SUMMARY: Rats injected in the hind paw with a mixture of Mycobacterium butirricum emulsified in mineral oil (FA) developed a severe polyarthritis that shared some immunological features with human rheumatoid arthritis. After this local administration, rats developed a secondary lesion (edema) in the contralateral paw, which is a hallmark of immune system activation. In vivo intravenous treatment with a monoclonal anti-very late antigen (VLA)-1 antibody (HA31/8) significantly reduced the edema formation in the contralateral paw. T cells isolated from contralateral paw draining lymph nodes of FA rats treated with HA31/8 showed a reduced cell proliferation in vitro, after stimulation with concanavalin A. Furthermore FACS analysis showed that the reduction in proliferation was concomitant to a reduction in the number of T cells positive to surface IL-2 receptor expression. Our data indicate that after in vivo treatment with a monoclonal anti-very late antigen-1 antibody, there is a beneficial effect on the development of the secondary lesion, which correlates to the reduced ability of T cells to proliferate in vitro as well as to a reduced surface expression of IL-2 receptor. The association of this antibody to other drugs interfering at other levels in rheumatoid arthritis may open a new therapeutic window. (Lab Invest 2000, 80:73-80).
\end{abstract}

$R$ heumatoid arthritis $(\mathrm{RA})$ is a chronic inflammatory disease with autoimmune features characterized by erosive bone and cartilage degradation in synovial joints (Harris, 1990). Chronic synovial inflammation in RA is characterized by mononuclear cell infiltration of tissue and synovial fluid. In these infiltrates activated T cells, with an increased expression of CD25 (Pitzalis et al, 1987), are thought to play a role in the initiation and the spreading of the inflammatory process either by directly damaging the tissues or indirectly regulating inflammatory cells through the cytokine and chemokine network (Buchan et al, 1988; Firestein et al, 1990). It has been shown that activated $T$ lymphocytes express on their surface a group of high molecular weight proteins called integrins constituted by noncovalent linked $\alpha \beta$ heterodimeric subunits of $95-200$ $\mathrm{kDa}$. One member of this family, very late antigen (VLA)-1, has been shown to act as a cell surface receptor for collagen and laminin and to be expressed on activated $\mathrm{T}$ cells in vitro and in vivo (Bank et al, 1991; Hemler et al, 1985). VLA-1 ( $\alpha 1 \beta 1$ integrin) is one of two major collagen/laminin binding integrins, and its

Received October 5, 1999

Address reprint requests to: Dr. Giuseppe Cirino, Dipartimento di Farmacologia Sperimentale via Domenico Montesano 49, 80131 Napoli, Italy. Fax:39081 7486403; E-mail: cirino@unina.it expression is up-regulated in persistently activated, cultured (2-4 weeks) T cells (Hemler et al, 1986 ) and rapidly induced on the monocyte cell surfaces by lipopolysaccharide or $\gamma$-interferon (Rubio et al, 1995). VLA- 1 is expressed on a high percentage of T cells isolated from the synovium of patients with RA (lannone et al, 1994; Laffon et al, 1989; Miyake et al, 1993; Odum et al, 1987; Panayi et al, 1992), suggesting that it may be involved in the process of targeting and maintaining activated $T$ cells at the sites of inflammation through interaction with resident matrix. There is evidence that blocking VLA-1 activity by selective monoclonal antibody prevents $T$ cell-dependent cytokine expression (Miyake et al, 1993). For this reason it is likely that blockade of the $T$ cell/matrix interaction by VLA- 1 inhibitors may relieve tissue damage not only by removing activated T cells but also by diminishing inflammatory cytokine levels. Several in vitro studies have attempted to clarify the role of these adhesion proteins, but their exact role in the inflammatory conditions in vivo has not yet been clarified. To our knowledge, up to now, studies on VLA-1 have only been performed in vitro on cells isolated either from synovia and spleen or on cell lines. Here we have evaluated the in vivo effect of HA31/8, a monoclonal anti-VLA-1 antibody, by using an experimental model of arthritis (Pearson, 1963; Pearson et al, 1961; Van 
den Berg, 1998). Furthermore, we have evaluated the possible interference at molecular levels produced by the in vivo administration of the monoclonal antiVLA-1 antibody on T cells isolated from lymph nodes of either arthritic or naive rats.

\section{Results}

\section{Effect of HA31/8 on Edema and Some Other RA Parameters}

As shown in Figure 1, HA31/8 $(0.3-1 \mathrm{mg} / \mathrm{kg})$ significantly inhibits edema formation in the contralateral paw. HA31/8 administration altered the edema development; indeed, the area under the time response curve is significantly reduced by about $45 \%$ when compared with the control value. Conversely, the control antibody at the higher dose tested $(1 \mathrm{mg} / \mathrm{kg}$ ) was inactive. Both the control antibody and HA31/8 were ineffective on the development of the primary lesion (eg, the injected paw; data not shown).

During disease development several clinical parameters, such as formation of eye and nose lesions, and ear and tail nodules, were also assessed. Nodule formation was significantly reduced by HA31/8 but not by the control antibody (Fig. 2). Moreover, $90 \pm 8 \%$ ( $n=10$ ) of Freund's adjuvant (FA)-treated rats presented eye and nose lesions; HA31/8 was significantly effective in reducing the number of lesions, causing an inhibition of $20 \pm 3 \%$ at a dose of $0.3 \mathrm{mg} / \mathrm{kg}(n=10$; $p<0.05)$ and $25 \pm 6 \%(n=10 ; p<0.05)$ at a dose of $1 \mathrm{mg} / \mathrm{kg}$. On the other hand, control antibody at a dose of $1 \mathrm{mg} / \mathrm{kg}$ was ineffective $(6 \pm 2.1 \%$; $n=10$; NS). The diameter of draining lymph nodes (DLN) was also measured by using a caliber. DLN from rats treated with $\mathrm{HA} 31 / 8(0.1,0.3$, and $1 \mathrm{mg} / \mathrm{kg})$ were significantly smaller (Fig. 3) than DLN isolated either from FA rats or rats treated with control antibody (1 $\mathrm{mg} / \mathrm{kg}$ ).

\section{FACS Analysis}

FACS analysis showed that T cells isolated from DLN, at day 21 , were $99.5 \% \mathrm{~T}$ lymphocytes. The distribution in naive animals was $58.3 \pm 4.0 \% \mathrm{CD}^{+}$and $42.3 \pm$ $4.6 \% \mathrm{CD}^{+}$. Total cell count is reported in Table 1. The treatment with FA caused an increase in cell count at day 21 (Table 1) but did not modify the $\mathrm{CD} 4^{+} / \mathrm{CD} 8^{+}$ ratio in FA rats, which was $60.5 \pm 4.4 \%$ and $39.5 \pm$ $3.4 \% \mathrm{CD}^{+}$and $\mathrm{CD}^{+}$, respectively. After treatment with anti-VLA-1 antibody (Table 1), there was a significant reduction in cell count, whereas the $\mathrm{CD} 4^{+} / \mathrm{CD}^{+}$ ratio was unchanged.

\section{T-Cell Proliferation}

Optimal incubation time and concanavalin A (ConA) concentration were determined preliminarily by using $T$ cells isolated from DLN of naive or FA-treated rats. T cells were incubated for 24,48 , and 72 hours with ConA $(0.5-5 \mu \mathrm{g} / \mathrm{ml})$. Thymidine uptake was maximal at 48 hours for $T$ cells isolated from contralateral paw DLN (Fig. 4). For the present study, the concentration of $5 \mu \mathrm{g} / \mathrm{ml}$ of ConA was selected as stimulus.

\section{Effect of Antibody Treatment on $\left[{ }^{3} \mathrm{H}\right]$ Thymidine Uptake}

After intravenous treatment with $\mathrm{HA} 31 / 8(0.1,0.3$, and $1 \mathrm{mg} / \mathrm{kg}$ ) or control antibody $1 \mathrm{mg} / \mathrm{kg}$ each for 3 days and after challenge in vitro of DLN T cells with ConA 5 $\mu \mathrm{g}$ we found a significant inhibitory effect of HA31/8 but not of the control antibody on T cell proliferation. Indeed, as shown in Figure 5, there was a significant reduction in thymidine uptake by $T$ cells isolated from contralateral paw of HA31/8-treated rats. Interestingly, when we analyzed basal uptake (without ConA stimulation) we found that HA31/8 treatment but not

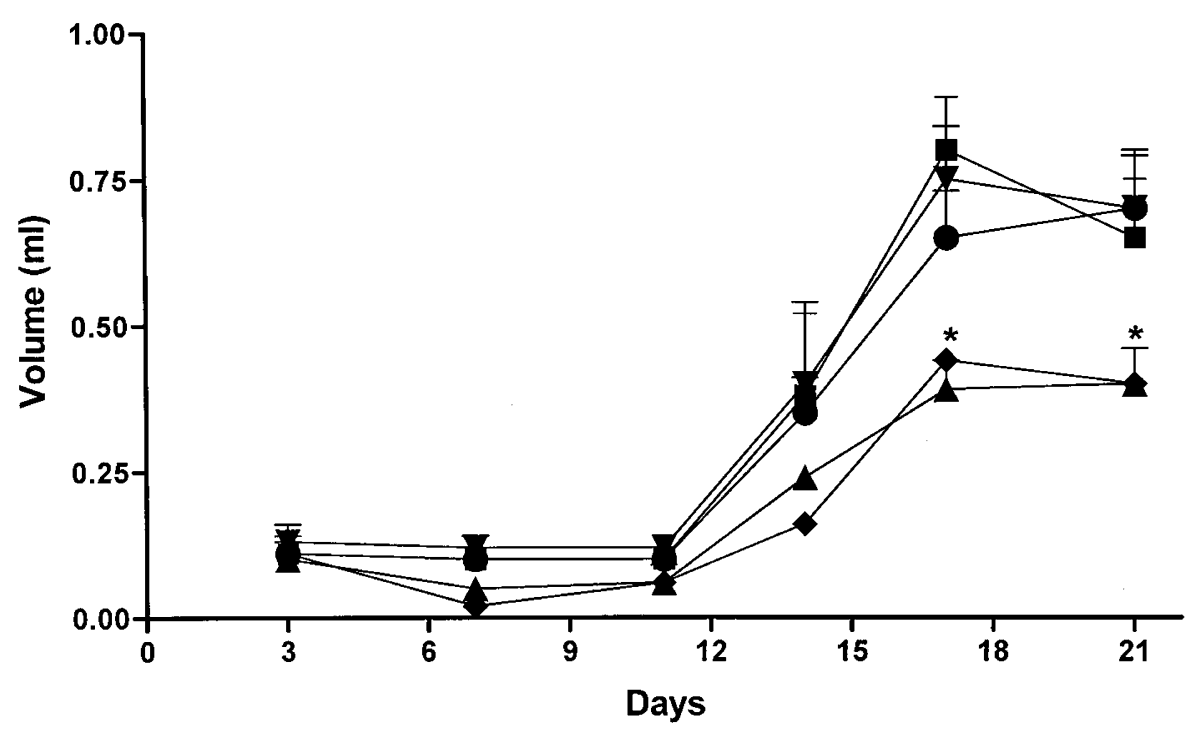

\section{Figure 1.}

The effect of HA31/8 at doses of $0.1(\boldsymbol{\nabla}), 0.3(\boldsymbol{\Delta})$, and $1 \mathrm{mg} / \mathrm{kg}$ iv $(\bullet)$ and of control antibody at a dose of $1 \mathrm{mg} / \mathrm{kg}(\boldsymbol{\bullet})$ on the edema induced in the contralateral paw (not injected) in FA rats $(\mathbf{\square}) .{ }^{*} p<0.05$ as determined by ANOVA followed by Dunnet's test for multiple comparisons 


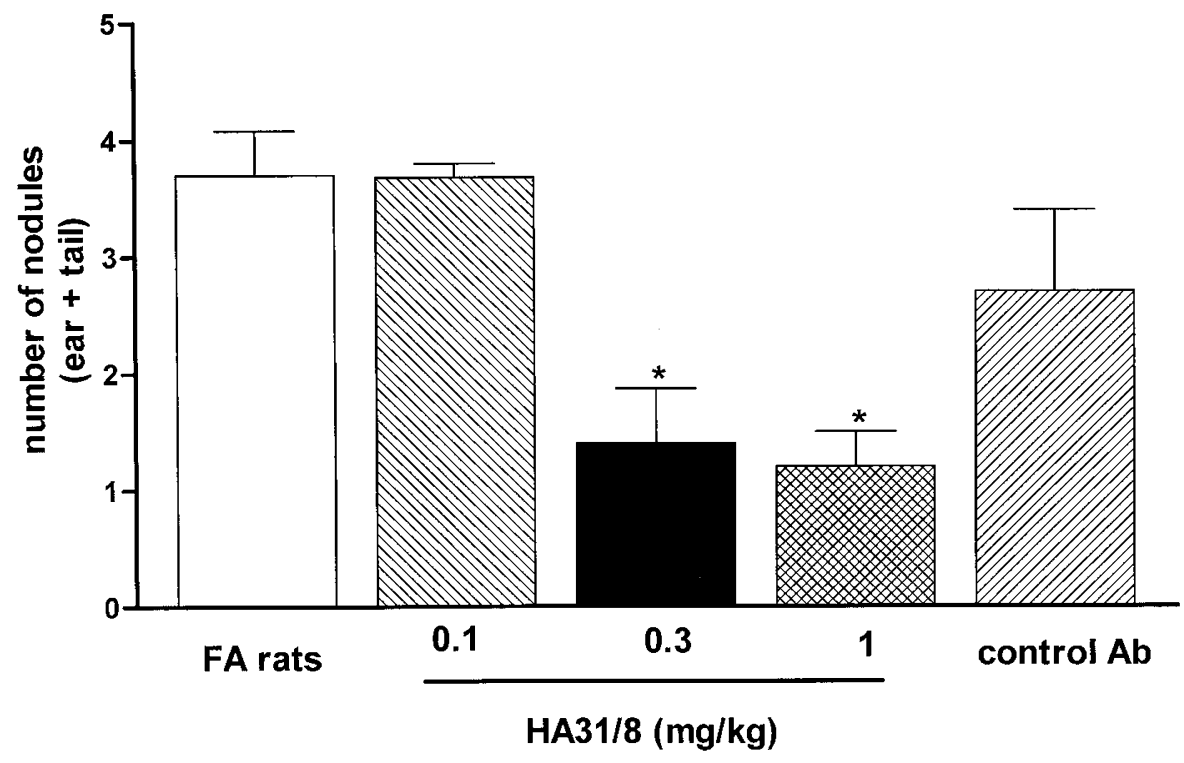

\section{Figure 2.}

Effect of HA31/8 at doses of $0.1 \mathrm{mg} / \mathrm{kg}(\mathbb{\mathbb { Q }}), 0.3 \mathrm{mg} / \mathrm{kg}(\mathbf{\square})$, and $1 \mathrm{mg} / \mathrm{kg}$ (絪). Control antibody (包) at the dose of $1 \mathrm{mg} / \mathrm{kg}$ iv was ineffective on nodule formation in FA rats. Data are expressed as mean \pm SEM $\left(n=10\right.$ for each group). ${ }^{\star} p<0.05$ as determined by ANOVA followed by Dunnet's test for multiple comparisons versus control value $(\square)$.

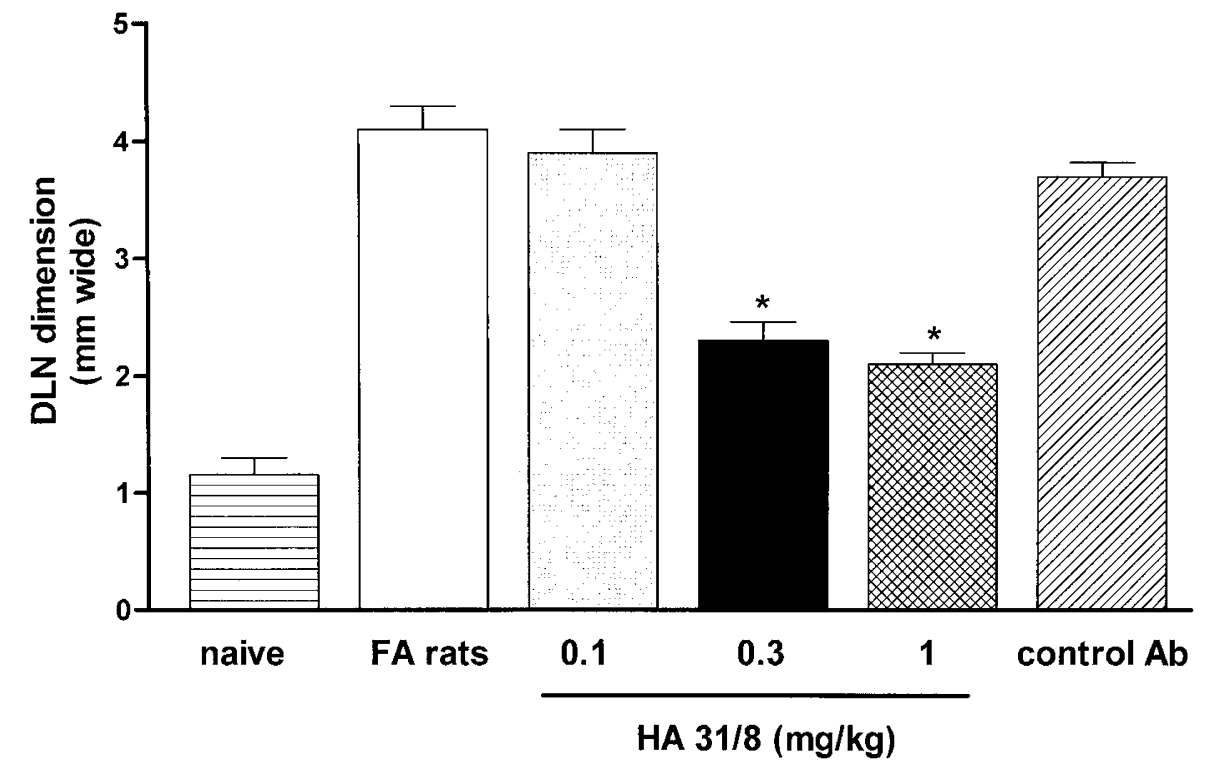

\section{Figure 3.}

Treatment with FA causes a significant increase in DLN diameters ( $\square$ ) when compared to naive animals (畻). Treatment with HA31/8 $0.3 \mathrm{mg} / \mathrm{kg}$ ( $\square$ ) and $1 \mathrm{mg} / \mathrm{kg}$ (罦) significantly reduced DLN diameter. Neither HA31/8 $0.1 \mathrm{mg} / \mathrm{kg}$ (grey bar) nor control antibody $1 \mathrm{mg} / \mathrm{kg}$ (四) caused a significant reduction in DLN diameter. * $p<0.01$ versus FA rats.

control antibody significantly reduced thymidine uptake to basal levels at 48 hours (Fig. 6).

IL-2R Determination. As shown in Figure 7A, the number of IL-2R-positive cells was significantly higher in FA rats than in naive rats. The anti-VLA-1 mAb significantly reduced the number of IL-2R-positive cells. When the data were analyzed as percent of mean intensity fluorescence (MIF), which can be interpreted as a measure of the number of receptors expressed on the cells, the effects were even more evident as shown in Figure 7B.

\section{IL-1 $\beta$ and TNF- $\alpha$ Plasma Levels}

IL-1 $\beta$ and TNF- $\alpha$ levels in plasma of rats treated with HA31/8 after the 21 days of treatment were not significantly different from control values. Indeed, $\mathrm{IL}-1 \beta$ and TNF- $\alpha$ levels in serum of naive rats were 
Table 1. Total cell count from naive, FA rats, FA rats treated with HA31/8 (0.1-0.3 mg/kg iv), or with control antibody

\begin{tabular}{lc}
\hline \multicolumn{1}{c}{ Treatment } & Total cells $10^{6}$ \\
\hline NAIVE rats & $7 \pm 0.38$ \\
FA rats (saline) & $37 \pm 6.2^{*}$ \\
HA31/8 $0.3 \mathrm{mg} / \mathrm{kg}$ & $10 \pm 2.0^{\tau}$ \\
HA31/8 $1 \mathrm{mg} / \mathrm{kg}$ & $12 \pm 3.2^{\tau}$ \\
Control $\mathrm{Ab} 0.3 \mathrm{mg} / \mathrm{kg}$ & $33 \pm 5.5$ \\
Control $\mathrm{Ab} 1 \mathrm{mg} / \mathrm{kg}$ & $28 \pm 7.1$ \\
\hline
\end{tabular}

${ }^{\star} p<0.05$ versus naive; ${ }^{\tau} p<0.01$ versus FA rats.

$28 \pm 6.8 \mathrm{pg} / \mathrm{ml}$ and $36 \pm 9 \mathrm{pg} / \mathrm{ml}$, respectively, whereas in FA rats, IL- $1 \beta$ and TNF- $\alpha$ serum levels were $83 \pm 7.4 \mathrm{pg} / \mathrm{ml}(n=10 ; p<0.01)$ and $78 \pm 3.6$ $\mathrm{pg} / \mathrm{ml}(n=10 ; p<0.01)$, respectively. Serum samples of $F A$ rats treated with $H A / 318$ showed no significant changes in IL-1 $\beta(84.3 \pm 7.3 \mathrm{pg} . / \mathrm{ml} ; n=10 ; \mathrm{NS})$ and TNF- $\alpha(78.7 \pm 3.6 \mathrm{pg} / \mathrm{ml} ; n=10$; NS) levels.

\section{Discussion}

The sequence of events required for the development of RA remains poorly defined and understood. Early histopathological alterations in the RA joint include morphological and phenotypic changes in the vascular endothelium and hypertrophy of the synovial lining of the cells. However, also in this stage, there is a modest perivascular accumulation of lymphocytes including $T$ lymphocytes. As the disease progresses, this T-cell infiltration becomes more pronounced and is accompanied by an influx of other cells such as macrophages, dendritic cells, and fibroblasts.

The role of lymphocytes in RA has been revised according to the progress that has been made in understanding the molecular basis of the cross-talk among cells involved in this pathology due to the powerful tools given to us by the field of molecular biology. It is now clear that lymphocyte migration through inflammatory tissue increases over days to weeks, eventually resembling that through lymph nodes. From this finding, it seems clear that lymphocytes in an inflammatory focus are in a dynamic state governed by entry from the blood, retention within the tissue, and migration into afferent lymphatics, with only a small proportion proliferating at the site of the lesion (Haskard, 1993). Recirculating lymphocytes enter lymph nodes by passing through paracortical postcapillary venules, which are characterized by their plump columnar endothelial cells. These vessels are now known as high endothelial venules and have been found to have properties that are adapted to support lymphocyte adhesion and transmigration from the blood into the lymph node parenchyma (Yednock and Rosen, 1989). By using a monoclonal antibody directed against VLA-1, we have studied the role of this integrin (VLA-1) in T lymphocyte function in FA arthritis.

To assess the role of VLA-1, we have isolated T cells from DLN rather than from spleen or synovial fluid as reported in several other studies. After in vivo treatment of FA rats with $\mathrm{HA} 31 / 8$, there was a significant reduction of the inflammatory response in the contralateral paw, which, in this model, is strictly linked to immune system activation. Treatment with the control antibody did not significantly reduce inflammation in the contralateral paw. From the time-edema volume course shown in Fig. 1 it emerges that HA31/8 treatment also reduced edema onset. No significant differences were seen between the doses of $0.3 \mathrm{mg} / \mathrm{kg}$ and $1 \mathrm{mg} / \mathrm{kg}$. This is further confirmed by the finding that both doses reduced the total area under the curve (time-paw volume in milliliters) of about $50 \%$. Treatment with HA31/8 also caused an amelioration of some clinical parameters that are typical of this model. Indeed, as has been shown in the original study describing this model, nodule formation is closely related to the severity of arthritis as well as eye lesions and balanitis (Pearson, 1963; Pearson et al, 1961). In FA rats treated with HA31/8 but not control antibody, the number of tail and ear nodules was significantly reduced as well as the number of nose and eye lesions. Overall, all these data show that FA rats treated in vivo with the HA31/8 antibody present a better clinical picture. The data also may imply an important role in the development of the secondary lesion for VLA-1 in this experimental animal model.

Because VLA-1 is expressed only on T lymphocytes that have undergone stimulation (Bank et al, 1991), to further investigate the promoting role of VLA-1 in the development of the secondary lesion, we used T cells isolated from peripheral DLN of arthritic rats. In vitro stimulation of DLN T cells isolated from FA rats with ConA caused a significant increase in labeled thymidine uptake when compared with DLN T cells isolated from naive rats. Although control antibody was ineffective, HA31/8 in vivo treatment caused a significant reduction in T-cell proliferation in vitro. Also in this case, the doses of 0.3 and $1 \mathrm{mg} / \mathrm{kg}$ gave a similar response. These data, together with the finding that swelling in the contralateral paw was inhibited by anti VLA-1 mAb, suggest that treatment with HA31/8 antibody is able to delay the disease development. It is likely that the beneficial effect of the anti-VLA- 1 mAb is linked to a reduced activation and, as a consequence, trafficking and proliferation of the T cells through the lymph node, which have been shown to be key features in this experimental model of arthritis (Cohen et al, 1985; Haskard, 1993; Holoshitz et al, 1984; Yednock and Rosen, 1989). Indeed, treatment with HA31/8 caused also a significant inhibition of the total cell count harvested by DLN.

It is of interest to note that T cell count from FA rats treated with HA31/8 was not significantly different from the naive count, further suggesting a possible reduction in cell trafficking and proliferation. In addition, maximal inhibition was already achieved with the dose of $0.3 \mathrm{mg} / \mathrm{kg}$, indicating that in our experimental condition this dose of antibody was enough to remove all the VLA-1 contribution. Of course we cannot exclude that the situation in the lymph nodes may reflect a more complex effect at the systemic level, not only 

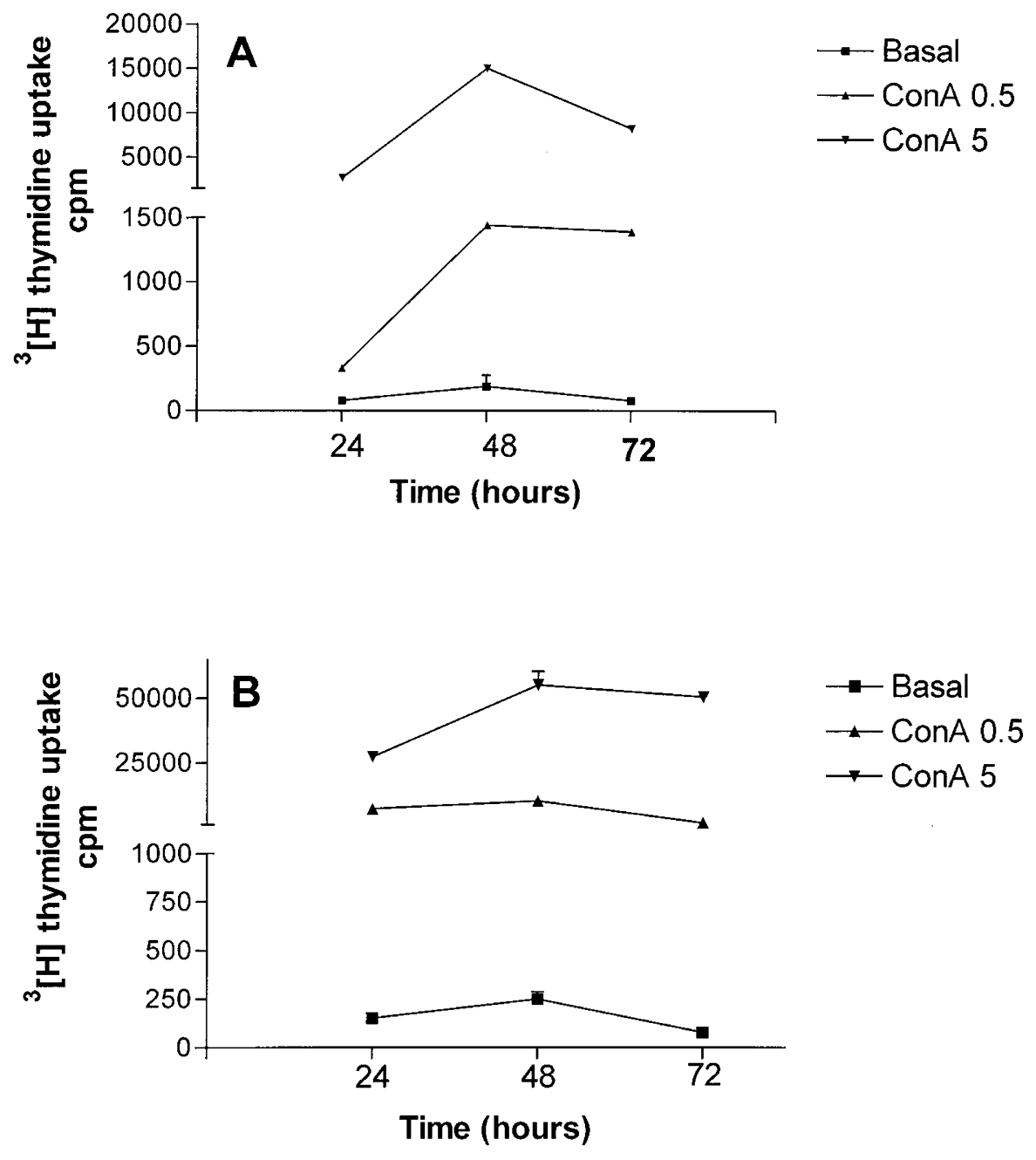

Figure 4.

A, The effect of 0.5 and $5 \mu \mathrm{g}$ of ConA at 24,48 , and 72 hours on T cells isolated from naive rats DLN. B, The effect of 0.5 and $5 \mu \mathrm{g}$ of ConA at 24,48 , and 72 hours on T cells isolated from contralateral paw DLN of FA rats. Data are expressed as mean \pm SEM $(n=3)$.

on lymphocytes, due to the wide distribution of this integrin. Indeed, elevated expression of vascular endothelial growth factor has been found in RA (Fava et al, 1994), and it has been shown that angiogenesis of human endothelial cells, promoted by vascular endothelial growth factor in vitro, is suppressed by antibody directed against $\alpha_{1} \beta_{1} \alpha_{2} \beta_{1}$ integrins (Senger et al, 1997).

The importance of the role of VLA- 1 in this RA model is further stressed by the finding that HA31/8 causes a pronounced reduction of $T$ cells expressing the IL-2 receptor as well as a reduction of the number of receptors expressed on the cells (MIF\%). Surprisingly the number of receptors per cells (MIF\%) of $\mathrm{T}$ cells isolated from FA rats treated with $\mathrm{HA31/8}$ is significantly below the naive level. This result together with the reduction in proliferation observed in vitro by isolated T cells implies an important role for VLA-1 in the development of the secondary lesion. This concept is further strengthened by the finding that the basal uptake (without ConA stimulation) of labeled thymidine, which is increased in arthritic rats, is brought back to basal level (naive animals level) after in vivo treatment with HA31/8. Indeed, this effect indicates that anti-VLA-1 antibody interferes with the mechanism(s) underlying lymphocyte activation after induction of the arthritis.

In conclusion our data taken together suggest that VLA-1 plays an important role, in this animal model of $R A$, in the development of the secondary lesion. The data also suggest that VLA-1 may represent a target to develop new drugs, which may improve the clinical treatment of rheumatoid arthritis.

\section{Materials and Methods}

\section{Antibodies}

HA31/8 is a hamster $\lg$ directed against the rat $\alpha 1$ integrin. The antibody was purified from hybridoma culture supernatant and has an endotoxin level of $<0.5 \mathrm{EU} / \mathrm{mg}$. Preliminary pharmacokinetic data analysis demonstrated that HA31/8 has a serum half-life of about 3 days (data not shown). Rabbit anti-rat CD4, 


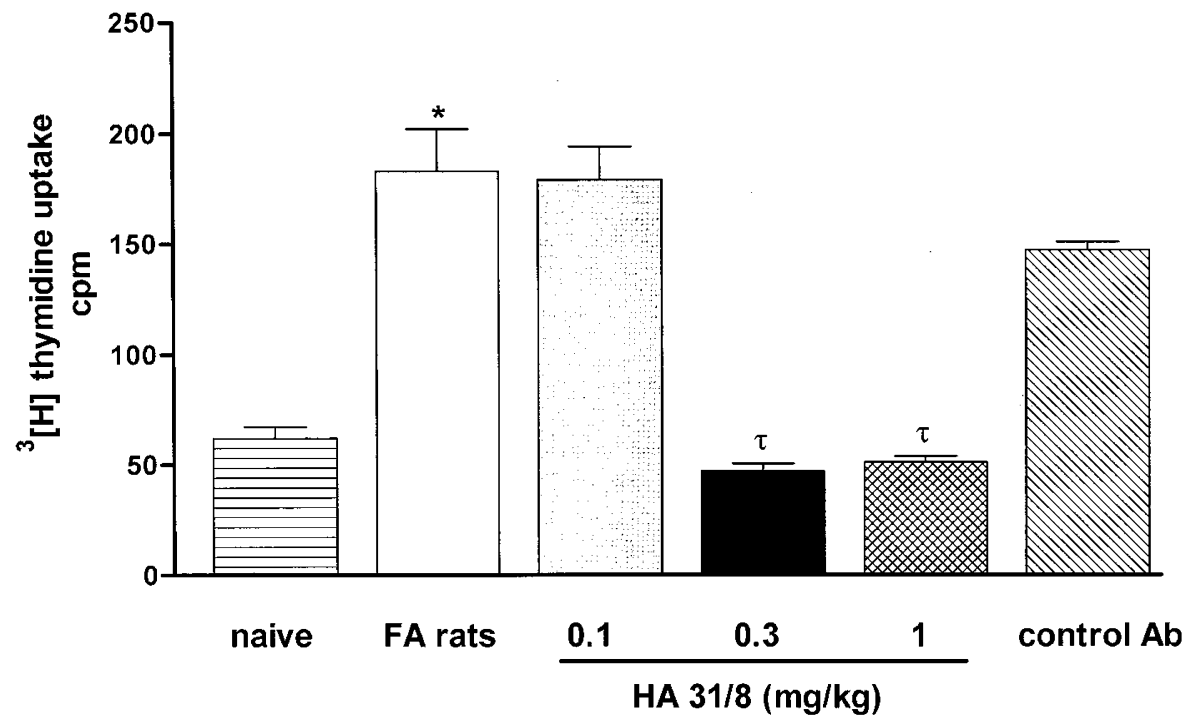

Figure 5 .

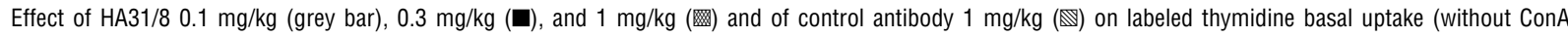
stimulation) of $\mathrm{T}$ cells isolated from DLN of contralateral paw. ${ }^{\star} p<0.01$ versus naive; $\tau p<0.01$ versus FA rats.

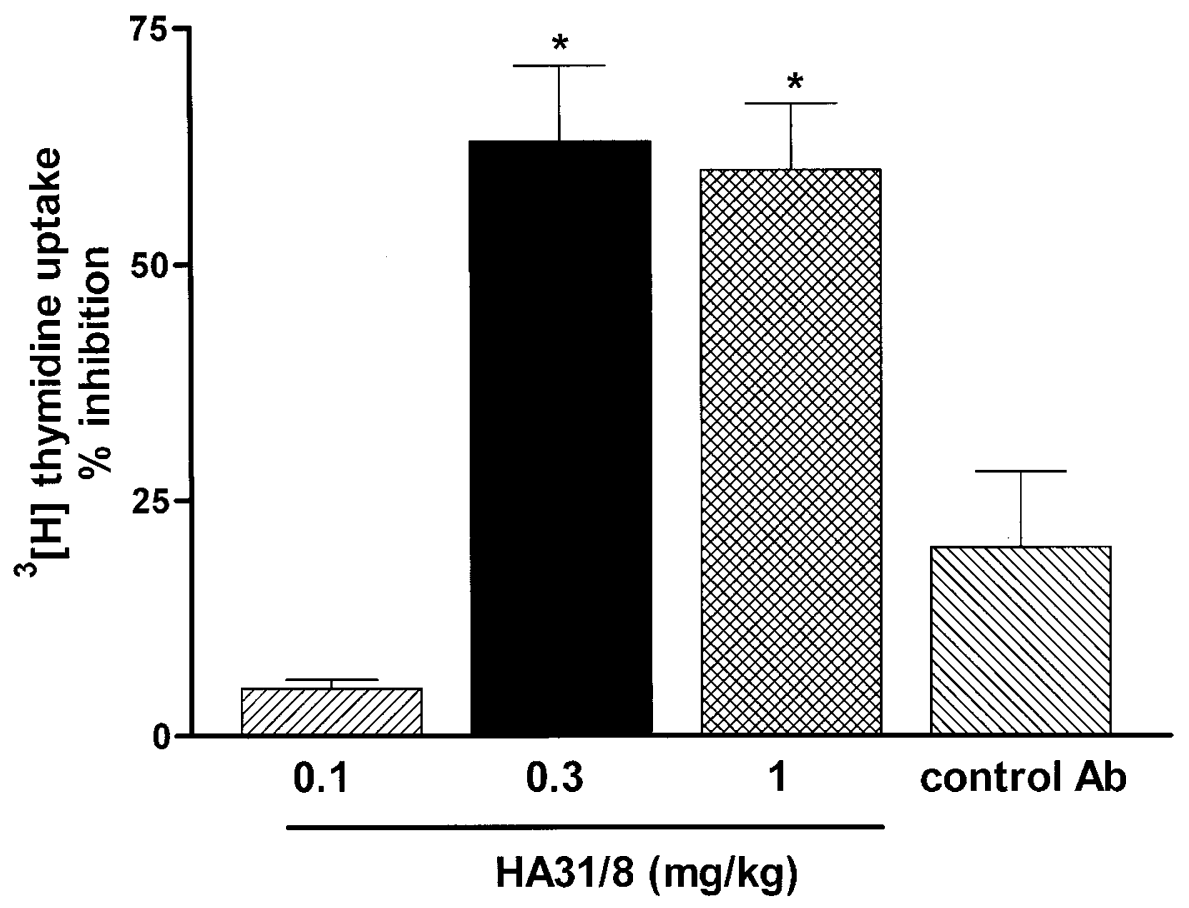

\section{Figure 6.}

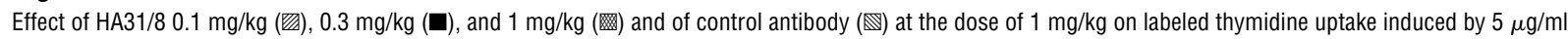
of ConA on T cells isolated from DLN of FA rats at 48 hours. Data are expressed as percent of inhibition versus FA rat T-cell proliferation. ${ }^{\star} p<0.01$. Control value for T cells stimulated with ConA $5 \mu \mathrm{g} / \mathrm{ml}$ was $55276 \pm 5199 \mathrm{cpm}$.

CD8, and CD25 (IL-2R) monoclonal antibodies were from PharMingen (San Diego, California). Fluorescein isothiocyanate-conjugated anti-rabbit monoclonal antibody was purchased from Sigma Chemical Co. (St. Louis, Missouri).

\section{Drugs}

Mycobacterium butirricum and Freund's adjuvant were purchased from Difco, and ConA was obtained from Sigma. Culture medium was RPMI containing 10\% fetal calf serum, L-glutamine $(2 \mathrm{~mm})$, penicillin $(100 \mathrm{U} / \mathrm{ml})$, streptomycin (100 $\mu \mathrm{g} / \mathrm{ml}), 2$-mercaptoethanol (50 $\mu \mathrm{M})$ (Sigma). $\left[{ }^{3} \mathrm{H}\right]$ thymidine was purchased from Amersham (Milan, Italy).

\section{Induction of Freund's Adjuvant Arthritis}

Male Lewis rats (120-140 g) were housed in propylene cages with food and water ad libitum. The light cycle 

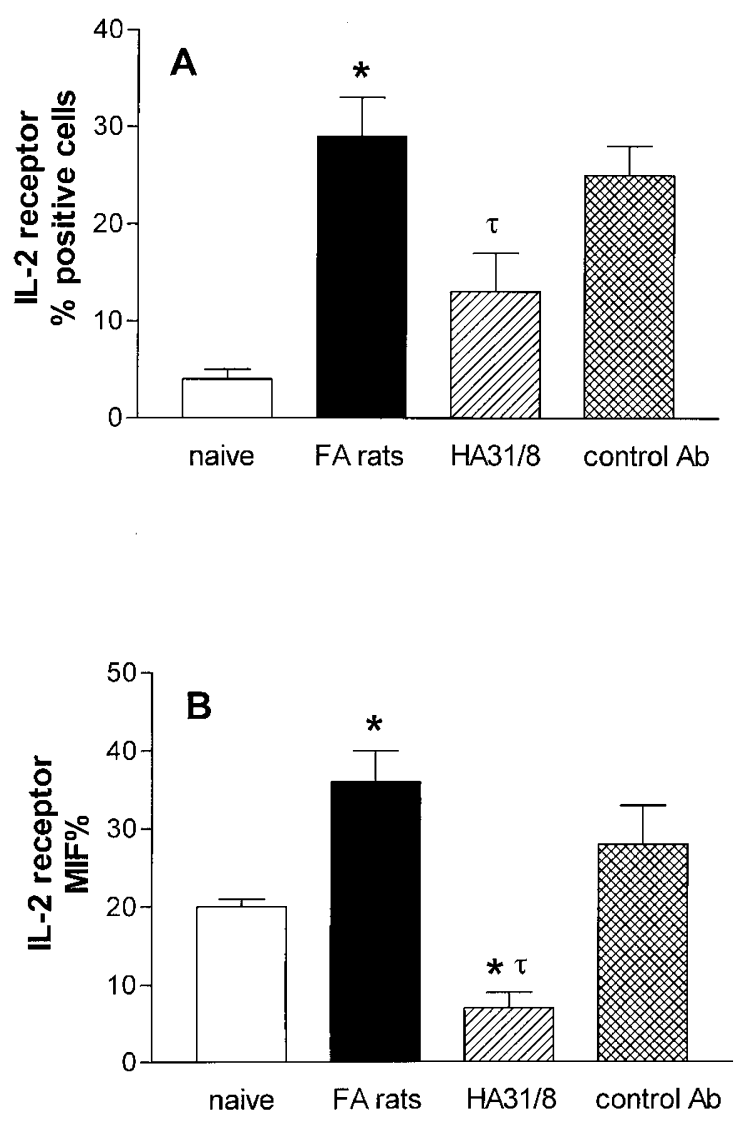

\section{Figure 7.}

A, Effect of HA31/8 and control antibody on IL-2 receptor-positive $T$ cells isolated from DLN of FA rats. ${ }^{*} p<0.05$ versus naive; $\tau p<0.05$ versus FA rats. $B$, The same data of $A$ analyzed as minimum intensity fluorescence percent (MIF\%) by FACS analysis; * $p<0.05$ versus naive; $\tau p<0.05$ versus FA rats.

was automatically controlled, and the room temperature thermostatically regulated to $21 \pm 1{ }^{\circ} \mathrm{C}$. Before starting the experiment, animals were housed in these conditions for 6-8 days. Arthritis was induced by injecting, in the right hind paw, $100 \mu \mathrm{l}$ of $6 \mathrm{mg} / \mathrm{ml}$ of Mycobacterium butirricum suspended in complete adjuvant (Pearson, 1963; Pearson et al, 1961; Van den Berg, 1998). The development of arthritis was assessed at days $3,7,11,14,17$, and 21 . The antibody or its control was administered from day 1 to 21 each for 3 days.

\section{T-Cell Proliferation Assay}

DLN were removed from the injected and contralateral paws of FA-treated rats at the end of each experiment at day 22 as previously described (lanaro et al, 1994). A single-cell suspension was obtained, counted, and resuspended at $2.5 \times 10^{6} \mathrm{cells} / \mathrm{ml}$ and dispensed at $100 \mu \mathrm{l} /$ well in 96-well flat-bottomed plates. Con A $(0.5$ or $5 \mu \mathrm{g} / \mathrm{ml}$ ) was added to each well, and the cultures were incubated at $37^{\circ} \mathrm{C}$ in an atmosphere of $5 \% \mathrm{CO}_{2}$, for 24,48 , and 72 hours. Cultures in triplicates were pulsed with $1 \mu \mathrm{Ci} /$ well $\left[{ }^{3} \mathrm{H}\right]$ thymidine for the final 6 hours of incubation, then harvested and counted in a $\beta$ scintillation counter.
Cell FACS Analysis. Cells were obtained from lymph nodes of the contralateral paw as described in the above paragraph. Cells were suspended in RMPI medium containing $5 \%$ fetal calf serum and $1 \%$ glutamine and incubated for 30 minutes at $4^{\circ} \mathrm{C}$ with primary antibody (1:50 dilution). Each cell suspension was tested with the following panel of mouse-anti rat monoclonal antibodies: anti-CD4, anti-CD8, and antiCD25 (IL-2R). Cells were then incubated with the fluorescein isothiocyanate-conjugated second antibody (1:100 dilution) for 30 minutes at $4^{\circ} \mathrm{C}$, washed twice, and resuspended in PBS/formaldehyde (0.5\%). Control samples were stained with the second-step reagent alone. Stained cells were analyzed on FACScan flow cytometer (Becton Dickinson, San Jose, California). Cells were gated using forward versus side scatter to exclude dead cells and debris.

Cytokine, IL-1 $\beta$, and TNF- $\alpha$ Plasma Levels. Cytokine levels were assayed in plasma samples by a rat IL-1 $\beta$ ELISA kit (Endogen, Woburn, Massachusetts) and TNF- $\alpha$ ELISA kits (Genzyme, Cambridge, Massachusetts) following the manufacturer's instructions.

\section{Statistical Analysis}

Data were evaluated by using ANOVA followed by Dunnet's test. The area under the curve was determined by using Simpson's rule. For statistical determination, two statistical computerized packages, INSTAT (Graphpad Software, San Diego, California) and PCS (Tallarida \& Murray, London, United Kingdom), were used.

\section{References}

Bank I, Roth D, Book M, Guterman A, Shnirrer I, Block R, Ehrenfeld M, Langevitz P, Brenner H, and Pras M (1991). Expression and functions of very late antigen-1 in inflammatory joint diseases. J Clin Immunol 11:29-38.

Buchan G, Barret K, Turner M, Chautry D, Maini RN, and Feldman M (1988). Interleukin-1 and tumour necrosis factor mRNA expression in rheumatoid arthritis: Prolonged production of IL-1 $\alpha$. Clin Exp Immunol 73:449-453.

Cohen IR, Holoshitz J, Van Eden W, and Frukel A (1985). T lymphocyte clones illuminate pathogenesis and affect therapy of experimental arthritis. Arthritis Rheum 28:841-845.

Fava RA, Olsen NJ, Spencer-Green G, Yeo T, Berse B, Jackman RW, Senger DR, Dvorak HF, and Brown LF (1994). Vascular permeability factor/endothelial growth factor (VPF/ VEGF): Accumulation and expression in human synovial fluids and rheumatoid synovial tissue. J Exp Med 180:341346.

Firestein GS, Alvaro-Garcia JM, and Maki R (1990). Quantitative analysis of cytokine gene expression in rheumatoid arthritis. J Immunol 144:3347-3351.

Harris ED (1990). Rheumatoid arthritis: Pathophysiology and implication for therapy. N Engl J Med 322:1271-1302.

Haskard DO (1993). Lymphocyte trafficking in inflammation. In: Maddison PJ, Isenberg DA, Woo P, and Glass DN, editors. Oxford textbook of rheumatology. New York: Oxford University Press, 296-310. 
Hemler ME, Glass D, Coblyn JS, and Jacobson JG (1986). Very late antigens on rheumatoid synovial fluid $T$ lymphocytes: Association with stages of $\mathrm{T}$ cell activation. $\mathrm{J}$ Clin Invest 78:696-702.

Hemler ME, Jacobson JG, Brenner MB, and Strominger JL (1985). VLA-1: A T cell surface antigen which defines a novel late stage of human T cell activation. Eur J Immunol 15:502508.

Holoshitz J, Matitian A, and Cohen IR (1984). Arthritis induced in rats by cloned $\mathrm{T}$ lymphocytes responsive to mycobacteria but not to collagen type II. J Clin Invest 73:211-215.

lanaro A, O'Donnel CA, Di Rosa M, and Liew FY (1994). A nitric oxide synthase inhibitor reduces inflammation, downregulates inflammatory cytokines and enhances interleukin-10 production in carrageenin-induced oedema in mice. Immunology 82:370-375.

lannone F, Corrigall VM, Kingsley GH, and Panayi GS (1994). Evidence for the continuous recruitment and activation of $T$ cells into the joints of patients with rheumatoid arthritis. Eur $\mathrm{J}$ Immunol 24:2706-2713.

Laffon A, Sanchez-Madrid F, Ortiz de Landazury M, Jimenez Cuesta A, Aziza A, Ossorio C, and Sabaudo P (1989). Very late activation antigen on synovial fluid $T$ cells from patients with rheumatoid arthritis and rheumatic diseases. Arthritis Rheum 32:386-392.

Miyake S, Yagita H, Maruyama T, Hashimoto H, Miyasaka N, and Okomura K (1993). Beta 1 integrin-mediated interaction with extracellular matrix proteins regulates cytokine gene expression in synovial fluid cells of rheumatoid arthritis patients. J Exp Med 177:863-868.

Odum N, Marling N, Platz P, Hofmann B, Ryder PL, Heilman C, Pederson FK, Nielsen CP, Friis J, and Svejgaard A (1987). Increased prevalence of late stage $T$ cell activation antigen (VLA-1) in active juvenile chronic arthritis. Ann Rheum Dis 46:846-852.
Panayi GS, Lanchbury JS, and Kingsley GH (1992). The importance of the $T$ cells in initiating and maintaining the chronic synovitis of rheumatoid arthritis. Arthritis Rheum 35:729-735.

Pearson CM (1963). Experimental joint disease: Observations on adjuvant-induced arthritis. J Chron Dis 16:863-874.

Pearson CM, Waksman BH, and Sharp JT (1961). Studies on arthritis and other lesions induced in rats by injection of mycobacterial adjuvant. J Exp Med 113:485-509.

Pitzalis C, Kingsley G, Lanchbury JS, Murphy J, and Panayi GS (1987). Expression of HLA-DR, DQ and DP antigens and interleukin-2 receptor on synovial fluid T lymphocyte subsets in rheumatoid arthritis.

Rubio MA, Sotillos M, Jochems G, Alvarez V, and Corbu AL (1995). Monocyte activation: Rapid induction of alpha1/beta1 (VLA-1) integrin expression by lipopolysaccharide and interferon gamma. Eur J Immunol 25:2701-2705.

Senger DR, Claffey KP, Benes JE, Perruzzi CA, Sergiou AP, and Detmar $M$ (1997). Angiogenesis promoted by vascular endothelial growth factor: Regulation through $\alpha_{1} \beta_{1}$ and $\alpha_{2} \beta_{1}$ integrins. Proc Natl Acad Sci USA 94:13612-13617.

Van den Berg WB (1998). Role of T cells in arthritis: Lessons from animal models. In: Miossec $P$, van den Berg WB, and Firstein GS, editors. $T$ cells in arthritis. Basel: Birkhauser Verlag, 75-92.

Yednock TA and Rosen D (1989). Lymphocyte homing. Adv Immunol 44:313-378. 